\title{
LIMNOLOGICAL NOTES ON NILSAGAR, NILPHAMARI, BANGLADESH
}

\author{
Md. Shafiqul Islam, Md. Ataul Gani, Md. Almujaddade Alfasane \\ AND MONIRUZZAMAN KHONDKER* \\ Department of Botany, University of Dhaka, Dhaka-1000, Bangladesh
}

Key words: Nilsagar, Phytoplankton, Water quality

During the British India rule a number of large sized ponds or man-made lakes were dug out by different Zamindars of that time to serve the needs of freshwater supply to the common people. Such water bodies of this category are still existing helter and skelter in different districts of Bangladesh ${ }^{(1)}$. Preliminary limnological information together with the diversity of phytoplankton and epipelic algae have already been carried out in some of those $\mathrm{e}^{(1,2,3)}$. Nilsagar of Nilphamari district is one of the famous man-made lakes of Bangladesh. Its basin was dug out by the Raja (= King) Birat. It has been heard that during the reign of Raja Birat there were many cow farms at Gorgram. Raja Birat dug a big pond or Dighi for the cows. It has got many names such as Birat, Birna, Binna. During 1980 's this aquatic body was reconstructed by the Ministry of Land and renamed as Nilsagar.

Khondker et al.(1) studied the water quality and phytoplankton community of Ramsagar. Nahar and Khondker(2) and Nahar et al. (3) studied the epipelic diatom and their relationships with the limnological parameters of Jaysagar. Aziz and Tanbir(4) studied a few plankton of Nilsagar. But there is no information regarding the water quality of Nilsagar. So, the present attempt has been made to study the water quality of Nilsagar and the status of phytoplankton community.

Nilsagar is located at Dhobdanga Mouza of Gorgram Union $14 \mathrm{~km}$ South-West of Nilphamari district headquarter. Its geographical location is $26^{\circ} 00^{\prime} 12.45^{\prime \prime} \mathrm{N}$ and $88^{\circ} 45^{\prime} 19.50^{\prime \prime}$ E. The area of the water body is 21.50 ha having an average depth of $9.50 \mathrm{~m}$. The entire dighi is surrounded by brick walls. The area has been considered as tourist spot and declared as birds sanctuary by district administration. Water sample from $10 \mathrm{~cm}$ depth was collected by dipping a two litre capacity polystyrene bottle from the southern part of the lake on 25th January, 2012 at around $15: 30$ hrs local time. The bottle was covered by dark papers and carried to the laboratory for limnological analyses. Triplicate Pyrex BOD bottle (125 $\mathrm{ml}$ cap.) was filled in situ and fixed by adding each of $1 \mathrm{ml}$ of manganous sulphate and alkaline iodide solution for DO analysis. Another one litre sample of the lake was fixed by adding Lugol's solution for the qualitative and quantitative analyses of phytoplankton. All the samples were transported to the Hydrobiology and Limnology laboratory, Department of Botany, University of Dhaka

*Author for correspondence: <mkhondker@yahoo.com>. 
and the chemical analyses was completed within next 24 hours. Methodologies followed have been described in Khondker et al. (5)

The recorded mean air temperature, water temperature, Sechhi depth, alkalinity, DO, $\mathrm{pH}$, TDS and conductivity of the lake were $19.27^{\circ} \mathrm{C}, 20.20^{\circ} \mathrm{C}, 53 \mathrm{~cm}, 0.60 \mathrm{meq} \Lambda, 11.64,6.96$, $32.00 \mathrm{mg} / \mathrm{l}$ and $126.33 \mu \mathrm{S} / \mathrm{cm}$, respectively. The concentration of soluble reactive phosphorus and silicate was very low. Mean value of the former parameter was $6.80 \mu \mathrm{g} / \mathrm{l}$ and the latter was $0.67 \mathrm{mg} /$. Nitrate-nitrogen concentration was remarkably low and showed $0.19 \mathrm{mg} \Lambda$ (Table 2).

Table 1. Abundance of phytoplankton of Nilsagar.

\begin{tabular}{lll}
\hline Division & Species & Density $\left(\times 10^{4}\right.$ ind $\left.\Lambda\right)$ \\
\hline Cyanophyta & Lyngbya limnetica Lemm. & 22700.37 \\
& Pelonema aphane Skuja & 4.89 \\
Chlorophyta & Crucigeniella crucifera (Wolle) Komärek & 2.43 \\
& Ankistrodesmus falcatus (Corda) Ralfs & 7.36 \\
& Ankistrodesmus falcatus var. radiatus (Corda) & \\
& Lemmermann & 0.06 \\
& Ankistrodesmus barnardi Kom. & 4.89 \\
& Closterium limneticum Lemm & 385 \\
& Scenedesmus sp. & 2.43 \\
& Tetraedron sp. & 4.89 \\
& Monoraphidium sp. & 9.83 \\
Euglenophyta & Trachelomonas volvocina Ehrenberg & 19.83 \\
& Euglena sp. & 2.43 \\
Bacillariophyta & Cyclotella sp. & 1926 \\
& Melosira sp. & 2.43 \\
Pyrrhophyta & Peridinium sp. & 4.89 \\
\hline Total & & 25077.73 \\
\hline
\end{tabular}

The water quality data of Nilsagar has been compared with those of Ramsagar ${ }^{(1)}$ and Joysagar ${ }^{(3)}$ (Table 2) and it has been seen that the mean alkalinity of water is almost same in all three water bodies. Mean $\mathrm{pH}$ value was almost similar in Nilsagar and Ramsagar. But the mean values of conductivity was similar to the Joysagar and 1.7 fold higher than Ramsagar. TDS is three times higher than Ramsagar. SRP is two times higher than Ramsagar but 11.7-fold lower than Joysagar. SRS is almost similar to Ramsagar, but 17fold lower than Joysagar. Mean nitrate concentration in Nilsagar was found to be 0.19 $\mathrm{mg} \Lambda$. This parameter was below $0.1 \mathrm{mg} /$ in Ramsagar. On the other hand, in Joysagar it was found to be $97.70 \mu \mathrm{g} / \mathrm{l}$. Mean DO value is to some extent better than Ramsagar (Table 2). 
Phytoplankton biomass as chl $a$ was $12.47 \mu \mathrm{g} / \mathrm{l}$ and that of phaeopigment $5.65 \mu \mathrm{g} / \mathrm{l}$. Both the values are two-fold higher than Ramsagar. Values of these variables were found to range from $7.91-19.83$ and $1.54-8.17 \mu \mathrm{g} / \mathrm{l}$, respectively from a mesotrophic pond(6). From phytoplankton, 13 genera and 15 species were recorded during the study period. The numerical values of phytoplankton population of the pond was found to be dominated by Cyanophyta followed by Bacillariophyta and Chlorophyta. The dominant species were Lyngbya limnetica, $22700.37 \times 10^{4}$ ind 1 ; Cyclotella sp. $1926.00 \times 10^{4}$ ind 1 and Closterium limneticum $385.00 \times 10^{4}$ ind 1 (Table 1 ). Chlorococcales was represented by four genera but their individual population density was very low (Table 1). In Ramsagar, Chlorococcales is represented by six genera and also with low population density indicating almost similar pattern with Nilsagar. The total density of phytoplankton was $25077.73 \times 10^{4}$ ind 1 .

Table 2. A comparison on limnological data of Nilsagar, Ramsagar ${ }^{(6)}$ and Joysagar ${ }^{(3)}$ lakes of Bangladesh.

\begin{tabular}{llcc}
\hline Parameters & Nilsagar & Ramsagar & Joysagar \\
\hline Scchi depth $(\mathrm{cm})$ & 53 & 75 & - \\
Air temp. $\left({ }^{\circ} \mathrm{C}\right)$ & 19.27 & 20.48 & 29.90 \\
Water temp. $\left({ }^{\circ} \mathrm{C}\right)$ & 20.20 & 22.50 & 27.40 \\
TDS $(\mathrm{mg} /)$ & 32.00 & 10.66 & - \\
Conductivity $(\mu \mathrm{S} / \mathrm{cm})$ & 126.33 & 73.66 & 109.20 \\
pH & 6.96 & 6.73 & 7.40 \\
Alkalinity $(\mathrm{meq} /)$ & 0.60 & 0.50 & 0.66 \\
DO $(\mathrm{mg} /)$ & 11.64 & 7.99 & - \\
PO4-P $(\mu \mathrm{g} / \mathrm{l})$ & 6.80 & 3.16 & 79.87 \\
$\mathrm{NO}$ 3-N $(\mathrm{mg} /)$ & 0.19 & 0.007 & 97.70 \\
SRS $(\mathrm{mg} /)$ & 0.67 & 0.77 & 11.43 \\
$\mathrm{Chl} a(\mu \mathrm{g} / \mathrm{l})$ & 12.47 & 5.92 & 174.10 \\
Phaeopigment $(\mu \mathrm{g} / \mathrm{l})$ & 5.65 & 3.65 & - \\
\hline
\end{tabular}

Since, the limnological information of the present study is based on the analysis of a single sample, it only reflects the water quality at a given time. However, by comparing the data of other studied water bodies the present water body could be said as nutrient poor as found in Ramsagar. The water body may be said to be oligo- to meso-eutrophic in nature having less organic content as indicated by a satisfactory concentration of DO $(11.64 \mathrm{mg} /)$ in the upper $10 \mathrm{~cm}$ depth of water.

\section{References}

1. Khondker M, Alfasane, MA Gani and MS Islam 2012. Limnological Notes on Ramsagar, Dinajpur, Bangladesh. Bangladesh J. Bot. 41(1): 119-121. 
2. Nahar K and M Khondker 2009. Addition to the list of freshwater diatoms (Bacillariophyceae) of Bangladesh. I. Family: Coscinodiscaceae, Fragilariaceae and Eunotiaceae. J. Taxon. Biodiv. 3: 9-12.

3. Nahar K, M Khondker and M Sultana 2010. Seasonal succession and diversity of benthic diatom of two wetland ecosystems of Bangladesh. Bangladesh J. Bot. 39(1): 29-36.

4. Aziz A and M Tanbir 2003. Algal flora of some northern districts of Bangladesh. Bangladesh J. Plant Taxon. 10(1): 63-78.

5. Khondker M, MA Alfasane, MS Islam, MAH Bhuiyan and MA Gani 2010. Limnology of Lake Bogakine, Bandarban. Bangladesh J. Bot. 39(2): 153-159.

6. M Khondker and MA Kabir 1995. Phytoplankton primary production in a mesotrophic pond in sub-tropical climate. Hydrobiologia 304: 39-47.

(Manuscript received on 3 October, 2012; revised on 21 November, 2012) 